\title{
6 \\ Confronting the Parlement of Paris, 1718
}

The menacing appearance of d'Argenson, the new keeper of the seals and president of the Council of Finances, so frightened contemporaries that they called him Rhadamanthus, a judge of the underworld in Greek mythology known for his stern sense of justice. But d'Argenson's efficiency as chief of police for Paris, his talent for making rapid decisions and his ability, even at the age of sixty-five, to work through the day and into the night, or vice versa, also won their respect. Experienced in government and an early supporter of John Law, he seemed fully capable of overcoming the Parlement of Paris, as though born for the moment. He had clashed with the tribunal over jurisdiction and assembled embarrassing personal files on some of its magistrates, as they had reason to know. In 1716 the Parlement, seeking its revenge, attempted to try him for embezzlement and fraud, a fate from which the regent providentially rescued him; but the experience naturally made him more hostile than ever towards the judges.

In the summer of 1718, d'Argenson assumed the key role in the regency's decisive confrontation with the Parlement and worked hard to achieve the final victory. Perhaps most important, he defined the central issue of the dispute as the question of legislative sovereignty, adding to it an important ideological dimension. His son René-Louis, who watched d'Argenson at work, likened him to Richelieu, although he might have adopted Pussort and Colbert as the better comparison. ${ }^{1}$

The magistrates took d'Argenson's new appointment as an affront and did not even consider registering the letters patent appointing him keeper of the seals, an unfavourable augury for their relationship. When, on 21 February 1718, d'Argenson responded formally to the Parlement's recent remonstrance, he added to its discontent. It was not that their old enemy, on his first encounter with the tribunal, displayed Rhadamanthine severity. On the contrary, as he stood in the Tuileries palace before a deputation from the Parlement and in view of the royal court, anxiety and clumsiness overcame him. He fumbled with his notes, dropped them twice and stammered as he read aloud. Bring the keeper of the seals a bit of candle, someone quipped from the rear; he cannot see what 
he is saying. His brief statement, to which he finally gave voice, also failed to impress. It merely reaffirmed the government's promise to pay interest on all its notes and loans, a bland, halting response that answered none of the substantive points in the remonstrance. ${ }^{2}$

At a divisive plenary session on 4 March, the Parlement appointed commissioners to examine d'Argenson's remarks but assigned them no deadline upon which to report. This tabled things until further notice - although not, as it turned out, permanently. For the time being, however, the Parlement's remonstrance of 26 January, which had so troubled the regent, became moot. D'Argenson, if inelegantly, had won a victory of sorts. All the same, the deliberations of 4 March made clear that the tribunal contained scores of magistrates eager to take him on.

Two presidents from the Enquetes chambers led a drive to confront the keeper of the seals with new, stronger remonstrances, which would have been the Parlement's first itératives remontrances since the Fronde. President Frizon de Blamont, prominent in earlier deliberations, urged the magistrates to remonstrate in defence of the fundamental laws of the realm, even if the Declaration of Vincennes did not seem to permit such a general remonstrance. But Frizon cited supporting precedents dating to 1561 and condemned the 'blow' dealt to remonstrances by ministers of the late king. In his person the ideas of sixteenth-century constitutional theorists, buried since the administration of Colbert, returned to the political surface.

For his part, President Henri Feydeau de Calende attacked the General Bank of John Law which, founded in 1716, had become a state-sanctioned central bank. All the kingdom's problems, he alleged, began with the Bank and the way its suspect paper notes endangered the royal debt. Where Blamont had defined the political issue, Feydeau concentrated upon the financial question, which happened to include unpaid augmentations de gages. When in his discourse he cited a precedent from 1648 , he thrilled his political friends but drew a warning from the first president, whom the regent had earlier scolded for making just such a reference. Feydeau also alluded to recent council decrees that, as he put it, had overturned traditions in the provinces, an unmistakable reference to Brittany, the deputies of whose Parlement lingered in Paris and had surely contacted their counterparts in the capital's tribunals. When their proposal for iterative remonstrances came to a vote, the Enquêtes presidents fell just six ballots short of victory. Such a close defeat showed that the government had aroused a lot of opposition in the tribunal. ${ }^{3}$

D'Argenson dealt with the deputies from the Parlement of Rennes on 17 February, when he responded to the remonstrance that they had delivered in January. Although he performed less awkwardly than at the Tuileries a few days later, he nevertheless surprised the Bretons with his curious reaction. The keeper of the seals declared that the regent would allow the Parlement to remonstrate for a new session of the Breton estates and for the recall of the soldiers, but the 
judges would have to rewrite their current remonstrance. Its language showed a lack of respect for the king, making it unacceptable as it stood. Bewildered, since they believed that their remonstrance observed the norms, the Bretons repeatedly asked d'Argenson to show them the actual words that had given offence, which, almost comically, he seemed unable to do.

The Parlement finally revised its remonstrance, excising in a puzzled way what it had to guess were the more argumentative passages, and sent it back to Paris, not much changed. Evidently satisfied, d'Argenson on 13 March agreed to transmit the bowdlerized version to the king. The regent's final answer, which d'Argenson handed the deputies on 15 March, was not very helpful. The government promised nothing about the Estates or the soldiers and left matters in the province where they had stood since December. It continued to collect taxes on its own authority, and the troops settled into indefinite occupation duty. D'Argenson did drop Noailles's insistence that the Parlement register the council decree of 21 December that had ordered the collection of those taxes; since some of the taxes were being paid anyway, he may not have seen the point. But this still left the province without its estates and under political tutelage. ${ }^{4}$

The rest of the winter and most of the spring slipped by anticlimactically, without much friction between the government and the tribunals. D'Argenson, however hostile to the Parlement of Paris, did not try to provoke it, now that the January remonstrance was no longer at issue. The Parlement, although still irate over the dismissal of d'Aguesseau, held its peace. The crisis that broke this undeclared truce took both sides by surprise and grew steadily in intensity, like a thunderstorm.

At the recommendation of d'Argenson and the Council of Finances, the regent in May 1718 issued an edict devaluing the livre by one-third in terms of specie. The government thus wrote up the value of its gold and silver stock and could pay its bills, denominated in livres, with less coin. The May edict also ordered the French to have their coin recast into smaller, lighter pieces bearing a higher face value. Finally, it encouraged holders of billets d'état to hand in some of these notes along with their specie, on the promise that the government would destroy the billets and thus shore up the value of those remaining in circulation. In a recent precedent, Noailles had also resorted to devaluation, although not to this degree and against the reservations of the Parlement of Paris. D'Argenson, anticipating strenuous opposition there, had the May edict registered by stealth in another superior court, the Cour des Monnaies, which had jurisdiction over currency disputes. ${ }^{5}$

The Cour published the new edict on 1 June, giving the Parlement no time to react, since the long Pentecost observance began almost at once. But in the ensuing hiatus the magistrates concluded that John Law, using d'Argenson as his proxy, was chiefly to blame. They saw the edict as resembling Law's Bank in its assault upon regular financial procedures and private family interests. They resented the fact that under its terms the government now owed them less gold 
and silver for their augmentations de gages, a development from which debtor magistrates, who now also needed less coin to pay their creditors, for some reason took little solace. By sending it to the Cour des Monnaies instead of the Parlement, moreover, the judges believed that Law and d'Argenson had intentionally circumvented proper procedure, preventing them from exercising their constitutional role of examining new law. But despite what the magistrates saw as his schemes to undermine the economy and constitution of France, Law stayed busy running his Bank and his new Company of the West and nothing else. The idea of devaluing the livre originated with d'Argenson, who saw the edict purely in financial terms. As president of the finance council, he simply needed the additional money to fund his budget.

Nevertheless, the assumption of malice lay behind everything the Parlement did throughout 1718; it believed that it was defending the whole constitutional and social order against dangerous innovations. On the other hand, d'Argenson, who also defined ideological issues starkly, began to accuse the Parlement of encroaching upon the king's rightful authority. Financial issues and constitutional ideas thus opened a gap between the two sides, and it widened steadily through the summer.

Commissioners appointed by the Parlement, having met continuously in the Pentecost interval, recommended that the tribunal join forces with its sister law courts in Paris, the Chambre des Comptes, the Cour des Aides and the Cour des Monnaies. In a plenary session on 14 June, the magistrates voted enthusiastically to invite deputies from these tribunals to meet with their deputies that very afternoon in the Chambre Saint-Louis of the Palais de Justice. The deputies would deliberate on how to wage a joint struggle against the May edict.

An assembly in the Chambre could only heighten widespread interest in the way current events matched those of the Fronde. In 1648 the Chambre SaintLouis, composed of representatives from these very tribunals, had attempted to dismantle the machinery of absolute government; and several magistrates, President Feydeau and others, drew explicitly upon this precedent. Mesmes, who supported the idea of a joint meeting, nevertheless disliked any such allusions: 'Please God that no one speaks of a junction of the companies as was done in 1648.' The first president had no wish to rekindle the wrath of the regent on this sensitive point, but few magistrates shared his caution.

Since the keeper of the seals did not want to relive the Fronde, he ordered the Cour des Aides, Chambre des Comptes and Cour des Monnaies not to participate in any such meeting. Similar orders had done no good in 1648, but this time the three tribunals, more easily frightened, complied. A new Chambre Saint-Louis did not therefore take place. As this was the best occasion for any concerted action on the part of the superior courts of Paris, d'Argenson might have counted this non-event as a personal triumph; but he never stopped worrying that such a session would convene in the near future. Throughout the summer, indeed, the three other tribunals modelled their political behaviour on 
that of the Parlement and looked to it for leadership. D'Argenson believed that this association, even if it did not progress to a joint meeting, itself endangered the monarchy and so argued in council sessions through the summer. ${ }^{6}$

As the dispute continued, First President Mesmes took an increasingly active role in the struggle against devaluation, which he called the most important issue to come before the Parlement in a long time. He probably hoped to advance the cause of his patron, the duc de Maine, and likely acted under the latter's supervision, even if this connection is not altogether provable. In any event, he presided over a tribunal that wanted to be led in the very direction that he was increasingly prepared to indicate. Mesmes began to work closely with the presidents and magistrates of the Enquêtes chambers whom he had previously tried to rein in, meeting with them in his home and seeking their advice. Prominent présidents à mortier also joined the discussions, notably Chrétien de Lamoignon, the grandson of the first president who had held office early in the late king's reign. With the leadership lining up against the May edict, the internal discipline associated with the Parlement of Louis XIV had clearly dissolved.

Once they received the old coins, the royal mints had thirty days in which to turn out new ones; as they did so, the May edict would take effect, whatever the magistrates might do. On 17 June, the Parlement therefore asked the regent to suspend execution of the recoinage edict and to send it to the Parlement for a vote by liberté des suffrages. The first president told the gens du roi, who were to convey this request, to report back quickly, 'as soon as you can, that will be best, because the affair is very important and urgent'. Orléans naturally rejected the plea, calling it 'extraordinary', and said the Parlement should simply issue a remonstrance. But remonstrances took time to write, occasioning delay that, given the Parlement's habitual use of that tactic, ironically worked in the government's favour at this point.

On 19 June, moving the process along, the Parlement condemned the edict with 'representations', which, being less formal, it could issue more quickly than remonstrances. The representations, reflecting virtually unanimous opinion, defended the Parlement's jurisdiction over the currency and argued that the edict would harm the French by costing them gold and silver in the reminting process and by subjecting them to inflation, the latter also damaging to the state. Orléans rejected all these points on the spot and the mints began to turn out the new coins, just as Mesmes had feared. ${ }^{7}$

On 20 June, in an extraordinary decree, a frustrated Parlement authorized oral and written remonstrances for the revocation of the May edict. Since the regent intended to dispose of this issue through remonstrances, this in itself gave no offence. But the decree went on to forbid anyone within the Parlement's jurisdiction to use reminted coins in any way and commanded notaries not to write contracts that listed the new values for the livre. Although the Parlement could cite precedents for these orders, none challenged royal legislation to this degree. Law charged that the Parlement had brazenly tried to impose its 
authority upon the regent, a claim that reflected loyalist opinion and showed the rise of ideological tension.

In order to rally the public, the magistrates intended to publish their decree before the Regency Council could annul it. They ordered the gens du roi to print the decree, to post it throughout Paris, and to send copies to all the subordinate tribunals within the Parlement's jurisdiction, more than half of France. But in the late afternoon of 20 June, within hours after the magistrates had concluded their session, the government closed their print shop and commanded all the city's printers to refrain from publishing their decree. Undeterred, the Parlement had it copied by hand and posted the copies in the Palais and throughout Paris, where the decree attracted public attention the next morning and for days thereafter. These measures took the tribunal well beyond the bounds of conventional resistance. ${ }^{8}$

Soon after the Parlement had finished for the day, d'Argenson, kept up-tothe-minute by private spies, described its actions at an extraordinary session of the Regency Council and asked for authority to punish the judges. Deliberations in the Council took several hours, lasting until 7 p.m., and the magistrates did not lack for supporters at the highest levels, then or in the days to come. Evidently, the duc du Maine spoke on their behalf, as did others, reportedly Marshals Villeroy and Villars, the core group of Orléans's opponents. The regent thus had to contend with a divided Council that, moreover, he had enlarged from its original twelve members to seventeen, making it even more unwieldy than before. Despite the dissent, Orléans got this conflicted Council to accept the recommendations of d'Argenson and to quash the Parlement's decree with a decree of its own. The competing decrees of Council and Parlement, each bearing the date of 20 June, appeared all over Paris the next morning, point and counterpoint.

But when the gens du roi brought the Council decree under seal to the tribunal, Mesmes was prepared for them, probably forewarned by Maine and his friends. The first president ostentatiously refused to receive the decree and sent it back to the government, unread, the seal not even broken. He declared that the king could only send the Parlement open legislative acts in the form of letters patent, edicts or ordinances, not sealed decrees, a fine point that d'Argenson interpreted as yet another affront to royal authority.

In retaliation, the Council on 21 June evoked from the Parlement all legal disputes involving the coinage, temporarily voiding its competence in this important sphere. Three days later, the regent discharged from his administrative councils three of the five magistrates of the Parlement who had served there from the beginning - Councillor Pucelle from the Council of Conscience and Councillors Ferrand and Menguy from the Council of the Interior. They returned to full-time service in the tribunal, but now as the regent's opponents. ${ }^{9}$

On 22 June, the duc d'Orléans, telling the gens du roi that he wished above all 
to preserve royal authority, ordered the Parlement to submit its remonstrance on 27 June, intending to end the coinage dispute then and there. This early deadline meant the magistrates had to work rapidly and in effect prevented them from issuing any more obstructive decrees, like that of 20 June. Increasing the pressure, the regent demanded that the Parlement register new letters patent that contained the evocation decree of 21 June, presumably his revenge upon the first president for having refused to open the nullification decree of 20 June. The magistrates decided that their remonstrance would include an article against the letters patent, which they boldly declined to register.

First President Mesmes, at the head of a deputation of magistrates, read the remonstrance aloud to the king, the regent and the court at the Tuileries on the morning of 27 June. Restating the key points in the representations of 19 June, the remonstrance asserted the Parlement's competence over all edicts involving the value of coins, as an issue of general importance and beyond the normal authority of the Cour des Monnaies. The tribunal again opposed the May edict on the grounds that a weaker livre harmed French economic interests abroad, eroded the resources of individuals through inflation and damaged the finances of the state.

Despite the haste in which they had worked, the authors of the document made a strong, clear argument, one that aroused much favourable comment. In tone and substance, the remonstrance was more moderate than might have been predicted, unequivocally affirming the magistrates' devotion to royal authority and justifying their opposition to the May edict by citing eight precedents back to 1571. Many judges ordered copies for their private use; and the Chambre des Comptes and the Cour des Aides, which presented remonstrances of their own, decided that their arguments would conform to those of the Parlement. ${ }^{10}$

The Regency Council met on the afternoon of 27 June and again on 30 June to decide how to answer the remonstrance. These turned out to be the crucial Regency Council meetings on the subject of the Parlement, the last at which a free exchange of opinion took place. Once again, the supporters of the tribunal attempted to shield it from retribution. The duc du Maine and the comte de Toulouse, along with Marshals d'Huxelles, Villeroy and Villars, all spoke in favour of their remonstrance and for the revocation of the edict, arguing for an overall change in policy. But d'Argenson opposed any compromise with the judges, the regent sided with him, and together they prevailed over Maine and his group. The Council, although still divided, voted to uphold the May edict and to condemn the Parlement for opposing it, leaving it to d'Argenson to compose a strong reply to the tribunal's remonstrance. He delivered this reply on 2 July at the Tuileries before the king, the members of the Council and the same deputation of judges who had presented the remonstrance six days earlier. ${ }^{11}$

If those judges, again led by Mesmes, anticipated another lacklustre performance by an inept keeper of the seals, they experienced a rude shock. On this 
occasion, d'Argenson displayed all the intellectual energy for which he had long been known. But his personal performance, however effective, was the least of things. It was his 900-word rebuttal that shocked the magistrates and sent them back to the Parlement in disarray.

D'Argenson disposed of the recoinage edict, the main topic of the remonstrance, in about two hundred words, bluntly upholding the new law and taking little note of the arguments against it. Then he changed the subject. The crucial issue, said the keeper of the seals, was not the edict but the Parlement's treatment of the king's legislative authority and what he called its misguided attempt to share or limit that authority. D'Argenson was only thirteen when, in 1665, Louis XIV presided at the Council of Justice; but from what followed it was as though he had attended the Council's sessions, so closely did his arguments resemble those of the councillors who wrote title I of the ordinance of 1667. Indeed, he had most likely studied the government's minutes of those sessions, still available today, and absorbed their contents.

Like the royal councillors of 1665, d'Argenson attributed legislative authority in its entirety to the king and all but excluded the Parlement from the whole process by which law was made and took effect. The king merely proclaimed his laws through 'the courts', said d'Argenson, avoiding the word 'Parlement'. These courts registered the laws as a sign of their 'indispensable' obedience to the monarch and not, he implied, to validate or to certify the legislation. The kings sent their laws to the superior courts merely from convenience; the laws could easily go to lower tribunals instead. It made no legal difference which courts received them first. All laws, in the resonating opinion of the keeper of the seals, existed entirely as the expression of the sovereign's will.

Although d'Argenson did not openly challenge the principles of vérification and liberté des suffrages, his manifesto in effect dismissed those ideas altogether. He all but said, and clearly meant, that the courts did not and could not verify, sanction, or assess the laws. Adopting the ideas and to some degree the language used in 1665 in the Council of Justice, he reaffirmed the absolutist concept of legislative power. Indeed, he took a step beyond where his predecessors had left off. Unlike title I of the ordinance or the declaration of 1673, the keeper of the seals in 1718 did not even admit that the parlements had a passive legislative role.

In addition to setting the Parlement straight on theory, d'Argenson condemned its recent plan to convene the other superior courts of Paris in the Chambre Saint-Louis. He must have feared that its sister tribunals would heed some new attempt by the Parlement to assemble the Chambre, for his statement adventitiously forbade it ever to do so. The king alone, d'Argenson proclaimed, held power in its entirety; and he used this power as he chose. He had chosen to delegate discrete portions to particular tribunals. But each tribunal, created separate and distinct, could not share delegated authority with the others, unless the king, the source of all their authority, permitted it. The tribunals 
could not join together by means of 'unions, invitations, or associations'. They did not represent the nation or speak for the parts of which it was composed; any such principle endangered the very foundation of the kingdom. D'Argenson's unexpected condemnation of the Chambre Saint-Louis and any claim by any institution to represent the nation, neither of which the remonstrance included, must have stemmed from unrecorded discourses or private expressions of opinion. In either case, his unanticipated denunciation came as another shock.

D'Argenson also surprised the magistrates when he made a brief but emphatic reference to the Fronde. The precedents cited in the remonstrance did include a currency decree from the Fronde year of 1652. D'Argenson might have ignored this citation, which the Parlement placed in a judicial not a political context; but he chose to single it out when he ordered the Parlement never again to refer to a period whose 'memory should be entirely abolished'. This unwonted stricture applied directly to those recent parlementary discourses which had evoked the events of 1648 and thus the Fronde itself. Finally, the keeper of the seals gratuitously insulted the magistrates by suggesting that their opposition to the May edict stemmed from their self-serving desire to free themselves from paying their share of the state debt. Of all his crisp judgements about the Parlement, this one struck closest to home. ${ }^{12}$

To sum up, the regent through his keeper of the seals had not only condemned the recent behaviour of the magistrates, he had also affirmed the principles of absolute government in language not heard since the 1660s. This resort to principle added an ideological dimension to the quarrel, raising the stakes by challenging the Parlement on theory. For this reason, the dispute could only grow more intense, involving not only policy but constitutional principle as well. It also began to attract unwelcome attention in the provinces, raising the prospect that other tribunals might join the fray. ${ }^{13}$

As Mesmes told the Parlement on 4 July, when he had the diatribe read aloud in a plenary session, d'Argenson's words appeared 'important' in the sense that they enunciated principles which, if left unchallenged, would undermine the whole body of constitutionalist thought and confer an inestimable psychological advantage upon the government. The magistrates agreed at once, from the most senior to the youngest among them, on the grounds that d'Argenson had attacked 'maxims as ancient as the Parlement' in favour of principles 'of great consequence' which 'it would be difficult to prove'. Cochet, a veteran président aux requêtes normally inclined to moderation, endorsed these assessments completely. 'The more one studies this matter', he concluded, 'the more one finds that it is important.' All agreed that they had to defend their constitutional traditions. On 8 July, the Parlement voted overwhelmingly to submit its third remonstrance of the year, in part against the recoinage edict but largely a full-fledged constitutionalist rebuttal to the absolutist theses of d'Argenson. Magistrates flooded the drafting committee with 
helpful memoranda - some quite extensive in their arguments, evidence and citation of precedent. ${ }^{14}$

The vote in favour of a new remonstrance meant that d'Argenson had failed to silence the Parlement; indeed, the regent complained to the gens du roi that the tribunal was now submitting remonstrances too frequently, as though to wear him down. So the government temporized on the date when it would receive the remonstrance and then, having fixed that date, abruptly postponed it by a week. As his excuse, the regent cited the extreme heat that oppressed Paris all that summer and supposedly threatened the health of the young king, who would have to endure another long session when the Parlement brought its remonstrance to the Tuileries. By no coincidence, however, the delay gave the mints additional time to turn out new coins, making the recoinage portions of the remonstrance increasingly pointless. Even so, the magistrates worked away at their document, which grew steadily in size.

On the morning of 26 July, the first president took all of forty-five minutes, so long had the remonstrance become, to read it to his assembled colleagues. The magistrates approved it with apparent unanimity and then considered whether or not, at the ceremony set for the Tuileries later that morning, the first president should read it aloud and in full, as a 'long sermon', in the words of Mesmes himself. Acting at the request of the regent, and thus relapsing into his consistent inconsistency, the first president proposed that he merely deliver the document in order to spare the king on a warm day. Probably he also wanted, by avoiding a public reading, to diminish its éclat, reinsuring himself with the government. But the magistrates voted overwhelmingly, 126 to 25 , for a full reading, no matter what the regent or the first president preferred; and with those instructions, Mesmes and a deputation set off for the Tuileries. It took more than an hour to present the remonstrance to Orléans, the Regency Council and the assembled court; but Louis XV withstood the experience without visible strain. ${ }^{15}$

The fresh remonstrance reasserted constitutionalist principles on the registration of laws, in studied opposition to d'Argenson's absolutist manifesto of 2 July. If the keeper of the seals had echoed Louis XIV's councillors from 1665, the Parlement drew heavily upon Pasquier and his constitutionalist successors. The old mentors might have written the tribunal's final text, so closely did it adhere to their tenets. Like their ancestors, the judges of 1718 accepted, to all appearances, the legislative sovereignty of the king, who, they acknowledged, wielded 'the only legitimate power in France, from which all others derive'. This unqualified confession attempted to discredit d'Argenson's charge that the Parlement intended to diminish royal authority. In another sixteenth-century convention, the remonstrance argued that all past kings had expected the Parlement to examine new legislation to ensure that it did not violate the fundamental laws of the realm. To honour this historic command and to fulfil their oath of office, the magistrates of the Parlement (not the judges of sister or sub- 
ordinate tribunals) must obviously receive the laws, deliberate upon them, and vote with liberté de suffrages. This was the irreducible meaning of registration; and registration, 'a necessary condition of the law', was an integral part of the monarchy, not to be separated from it. The magistrates stated all these theses with as much emphasis as possible.

They thus set precedent, tradition and constitutionalist theory in direct opposition to the absolutist principles of the keeper of the seals and underlined the theoretical distance between them. Recent scholars have treated both manifestos as reflecting only the fringes of French political thought, so extreme as to be almost outside the spectrum. In fact, the contrasting statements clearly stated, for the benefit of a new generation, the ideological tension between princes and parlements that had originated in the sixteenth century, survived for most of the seventeenth, and had inevitably reappeared, now that Louis XIV was dead. Such a collision of ideas and principles was in the nature of things, as the Introduction to this study argued. ${ }^{16}$

Although the government chose not to answer the remonstrance, wishing to break off the verbal duel now that the mints were producing the new coins in quantity, the tribunal, resilient as always, took up another financial issue. Summoning Charles Trudaine, the prévôt des marchands of Paris, over whom it had administrative jurisdiction, the Parlement learned from him that the government was selling more rentes on the Hôtel de Ville than it had funds to pay for. This fresh excursion into finances, consuming the first weeks of August, may have been intended, as Saint-Simon charged, to win the political support of the rentiers of Paris, whose interest payments the government could not meet.

The magistrates decided to issue yet another remonstrance, this time on general financial policy, and to include in it a critique of d'Argenson's meaningless answer to their remonstrance of 26 January. The commissioners appointed in February to study that response now got to work. What would have been the fourth remonstrance of the year targeted John Law and his Bank, which included in its deposits tax revenues that in principle belonged under the control of regular financial officials. The magistrates resented this interference in financial administration and saw his overall plans as a vast confidence scheme, perpetrated by a disreputable foreigner. The problem, said President Feydeau bluntly, was how to 'bring this man down'.

After a heated discussion on 12 August, in which the magistrates denounced Law by name or as 'that foreigner', the tribunal issued a decree that compared in audacity with its decree of 20 June on the coinage. The Parlement ordered the Bank reduced to its original status as a private institution, instructed it to return state funds to regular fiscal officials, and banned all foreigners, meaning Law, from the administration of finances. President Feydeau, who proposed the decree and condemned John Law by name, saw it pass by an overwhelming margin, 130 to 29 , supported by both junior and senior magistrates, including half the présidents à mortier. 
The next question was in what manner the Parlement would publish its decree. The first president and the dean, Le Nain, urged their colleagues to show moderation. But on 18 August, after another overwhelming vote, 139 to 40, the Parlement issued the decree as conspicuously as it could - by having it read aloud at a plenary session, with the doors and windows flung open, in the full view and hearing of the crowds that thronged the galleries of the Palais de Justice. It also ran copies off its printing press, sent them to subordinate tribunals, and posted them in Paris. The diarist Barbier saw people reading the decree all over the city.

The new decree appeared at a bad time for the financial health of Law's Company of the West, which was closely related to the Bank. After a six-month suspension, Law had just resumed selling Company shares. Since its prospects appeared bright, a perception heightened by its acquisition of the tobacco revenue farm, the Company saw its stock rise nicely in value into the summer of 1718. When the Parlement published its decree of 12 August, the run-up ended, and prices fell off sharply. Law placed the losses at 100 million livres and derided the magistrates as financial simpletons. ${ }^{17}$

Most important, the decree of 12 August, which went well beyond anything that the Parlement had previously done, appeared to have serious constitutional implications. Loyalists like Saint-Simon saw it as a frontal attack upon royal authority and a near revolutionary effort to insinuate the Parlement into affairs of state, an assessment shared to a degree by some modern scholars. The judges themselves, as we have seen, believed that they were upholding tradition, precedent and the laws of the realm against unprincipled innovations. One of those infrequent but inevitable breakdowns in the French system of government therefore loomed ahead.

The magistrates made a malicious interpretation of their intentions even more believable when, on 22 August, they demanded that the regent allow them to inspect his financial registers, seeking proof that the government had in fact destroyed, as it had promised, the billets d'état acquired in the recoinage process and by other means. The Parlement also began to deliberate on the government's failure to pay its creditors the interest that it owed them, with the full intention of exploiting this issue as well. When the gens du roi presented these concerns to the duc d'Orléans, he turned and walked away, astonished at the tribunal's presumption. ${ }^{18}$

On the afternoon of 19 August, as Saint-Simon met in his Paris mansion with a frightened John Law (more dead than alive, said the memoirist), he received two unexpected visitors - Henry Jacques de Caumont, duc de La Force, and Louis Fagon. The former was vice-president of the Council of Finances and was about to be named to the Regency Council, the latter a junior councillor of state. They had just come from the regent who, alarmed by the Parlement's decree against John Law, had ordered them to confer with both Law and Saint-Simon and advise him what to do. For the first time, Saint-Simon dared hope that Orléans, 
whom he regarded as politically careless, at last understood that he faced a real crisis. Unknown to Saint-Simon, Orléans was in fact working fourteen hours a day in an effort also to solve international problems. He had just negotiated the Quadruple Alliance with England, the United Provinces and Austria, agreeing to provide money to his allies in any future war with Spain. This pledge made the financial interference of the Parlement all the more troublesome. ${ }^{19}$

Saint-Simon and his fellow conspirators decided that Orléans should try to impose his will in a lit de justice, the logical next step now that the Parlement was ignoring the annulment decrees of the Regency Council. But if the friends of Orléans raised this idea in Council, they risked seeing the duc du Maine and his group change the mind of the regent, possibly by contending that a trip to the Parlement would endanger the health of Louis XV, given the oppressive heat. As Maine was superintendent of the king's education and saw him daily, even occupying an apartment in the Tuileries, such an objection could not be dismissed out of hand. Besides, Maine would inevitably alert the magistrates as to what they should expect, allowing them to plan the most effective rejoinder. Finally, the conspirators did not believe that the regent, known for equivocation, would persevere for very long.

At length Saint-Simon hit upon the solution: they would hold the lit de justice in the Tuileries itself, making it unnecessary for the king to travel the streets of Paris, and they would keep everything secret until the very day of the ceremony. To this end, they would have the regent convene the obligatory Council session on the morning of, and just before, the lit de justice, catching Maine and the Parlement by surprise. So, indeed, it was to be, once the regent agreed to everything.

D'Argenson, informed of the plan, supported it at once, although he insisted that he needed several days in which to prepare new laws for the lit de justice. The abbé Guillaume Dubois, the former tutor of the regent and soon to be his secretary of state for foreign affairs, also joined in; but he seems to have wavered, possibly hoping to mediate some compromise with the Parlement. A more important, less hesitant recruit was the young Louis-Henri de Bourbon-Condé, duc de Bourbon, titular chief of the Regency Council and head of the powerful Condé family, princes of the blood. Law had shrewdly conferred shares of Bank and Company stock upon 'Monsieur le Duc', making him wealthier than ever; the regent now promised to appoint him superintendent of the king's education in place of the duc du Maine, still another reward. Meanwhile, Saint-Simon quietly attended to the lit de justice paraphernalia, the benches, podiums and draperies. He also fortified Orléans with frequent visits; but it was not until the Parlement took its initiative on the billets d'état and threatened further action on the rentes, that he dared believe the regent would execute the plan in full. ${ }^{20}$

At a session of the Regency Council on 21 August, d'Argenson presented a masterly summary of what he regarded as the Parlement's recent challenges to royal authority. He then read the tribunal's new decree against John Law and the 
General Bank and took immediate issue with it, refuting the precedents that it had cited and its overall theme. In words which he again drew from absolutist thought, and likely from the Council of Justice of 1665, the keeper of the seals defined the current issue as to whether the king's subjects were to obey the monarch or the Parlement, 'and which of the two has legislative power'. Once the question was put that squarely, the Council had little choice but to quash the Parlement's decree. The regent announced that the Council would reconvene in the near future to approve the full text of an annulment decree and to decide what else to do. Just as Saint-Simon had feared, however, word leaked out that the Council intended to void the Parlement's decree, and a rumour began to circulate that the king would soon hold a lit de justice; but that rumour could not have come from the Regency Council, where the matter had not been discussed. ${ }^{21}$

Tension, like the heat, became oppressive, spawning anxious speculation and feverish, contradictory rumours. Foreign ambassadors predicted turmoil; Saint-Simon and his friends weighed the prospects of civil war. The regent's mother, Elisabeth Charlotte, despaired of her son's life. The friends of Maine, also pondering an uncertain future, feared that cells in the Bastille awaited them. John Law hid out in the Palais Royal, frightened by reports that the Parlement intended to hang him. When at last he returned home, several judges paid him an unexpected courtesy call, anxious to reinsure themselves should Law win out after all. ${ }^{22}$

Orléans scheduled the next meeting of the Regency Council and the lit de justice both for Friday, 26 August; although bedridden by a worrisome attack of fever, he issued the necessary orders into the early hours of that morning. At 5 a.m., drumbeats reverberated in the city, as more than thirty companies of cavalry, dragoons, guardsmen and musketeers, all newly paid, took positions in and around the Tuileries, the rue de Richelieu, and the Saint-Germain market, the key points for crowd control. Messengers notified members of the Regency Council that it would meet at 8 a.m. At 6 a.m., the master of ceremonies, Michel Desgranges, arrived at the Parlement, where barely a handful of magistrates had begun to assemble.

Since the first president was still at home, Desgranges informed the senior président à mortier, Lamoignon, that the king would hold a lit de justice that day. In the event of any resistance, the master of ceremonies had orders to command the judges to leave the Palais de Justice and to cease exercising their offices. But Lamoignon merely sent for Mesmes who, arriving hurriedly, convened an immediate plenary session, where the gens $d u$ roi, having seen the regent at the Palais Royal, announced that the lit de justice would take place at 10 a.m. in the Tuileries. Saint-Simon and his friends had planned well; everything moved with machine-like precision. ${ }^{23}$

As the magistrates pondered how to react, the members of the Regency Council arrived at the Tuileries for their meeting. Orléans, as Saint-Simon noted with relief, seemed fully recovered from his fever, and an unusual resolution 
illuminated his face and worked its way into his posture. In a surprise, the regent took the comte de Toulouse aside and induced him to leave the meeting and to take the duc du Maine with him. By departing, Orléans persuaded Toulouse, they would spare themselves humiliation and anguish; their absence, he did not need to explain, would also make the session go more smoothly.

When the meeting began, the princes having exited quietly, the regent revealed that he was holding a lit de justice short notice to register the Council's annulment of the Parlement's decree of 12 August. If he were to send the decree to the Parlement in the ordinary way, he explained, this would only hand the judges another occasion to disobey the king and further compromise royal authority. The keeper of the seals, who spoke next, expanded upon his ongoing charge that the Parlement was using remonstrances to claim a role in affairs of state and finances. The Council's new annulment decree, he declared, included regulations on remonstrances, 'in the manner of a code', to curtail this abuse. This, of course, went well beyond what the Council had agreed to on 21 August.

D'Argenson then read his annulment decree, which included the new restrictions on remonstrances, and letters patent that restated everything for purposes of public law. The severe language in these documents astonished the Council members, and the regent astounded them with the forthright way that he endorsed the texts. No one had imagined that he would ever adopt so harsh a tone or take so firm a line with the Parlement. Silence descended upon the Council session; Saint-Simon said that one could have heard a mite walk. When Orléans asked for the votes, everyone approved - the duc du Bourbon, with enthusiasm; the friends of Maine, grudgingly. Most members said little or nothing, except the duc de Noailles, who, chagrined at the humiliation of his protégés, spoke at some length, without effect.

Having surprised his Council, the regent truly stunned it when he declared that he would also strip Maine and Toulouse of their status as princes of the blood and reduce them to their original rank of dukes and peers. On legal grounds, as well as from social envy, most peers, especially Saint-Simon, had taken offence when the late king, advancing his legitimized sons, made them princes of the blood. Politics now spurred the regent to diminish his rivals, returning them to their previous status. As a junior peer, the duc du Maine had no claim to oversee the king's education, so the regent awarded the superintendent dignity to Bourbon, who glowed with pleasure in his seat. Marshal Villeroy, perhaps Maine's closest supporter, deplored the unhappy state of his friend, but Orléans heatedly denounced Maine as an 'enemy revealed', voicing the resentment that he had felt for at least the three years of his regency. ${ }^{24}$

Meanwhile, the magistrates, enveloped in their heavy red robes and numbering some 150, a substantial complement, left the Parlement at 9.30 and made their sweltering way along the Quai des Orfèvres, across the Pont Neuf, and up the Rue Saint-Honore towards the Tuileries. Few onlookers lined the streets, dashing any hopes for public intervention. At the Tuileries, where soldiers filled 
the courtyard, an escort guided them into a great antechamber on the first floor, where they found Saint-Simon's benches and paraphernalia set up much as they would have been in their own Grand-Chambre. Taking their places on the lower benches, while peers and dignitaries filed into tiers of seats along the sides, some magistrates, especially Mesmes, noted with dismay the unexpected absence of Maine and Toulouse, whose seats Saint-Simon and the duc du Sully, the senior peers in attendance, triumphantly occupied. The king appeared, preceded by Orléans, Bourbon and the prince de Conti, and made his way to a throne on a platform in a corner.

D'Argenson took his seat in an armchair beneath the throne, a small desk and papers before him, the royal seals at hand. After the preliminaries, an uncomfortable silence descended, as the keeper of the seals sat motionless and menacing, savouring the moment, his enemies helpless before him Rhadamanthus, true to life. At last he rose and began to speak, so firmly that his voice carried across the vast chamber and into the public area where spectators crowded round. His words surged through the magistrates, leaving them visibly shaken. When he had finished, d'Argenson had the clerk Gilbert read aloud the annulment decree and the letters patent that the Council had just approved. As these texts - the discourse, the decree and the letters patent - all came from the pen of d'Argenson and dealt with the Parlement in similar ways, we may treat them as a single document. They represented the strongest assertion of the principles of absolute government in more than fifty years.

D'Argenson castigated the Parlement for trying to usurp royal authority, arrogating to itself power that belonged to the king alone, his main thesis during the entire clash. He had said as much on 2 July, but he now elaborated on the charge and embellished it with concurrent accusations. By its recent decrees, d'Argenson declared, the tribunal had tried to lift itself above the other superior courts of Paris, claiming authority over financial issues that lay outside its sphere. It had abused remonstrances by issuing too many and had attempted by remonstrances to coerce the king. Its decrees of 20 June and 12 August proved that the Parlement believed that it could issue orders contradicting the king's very words, no matter how precisely chosen. It thought itself able to do what it wished over and against the king who, relegated to second place, could no nothing without its assent. This could only mean the Parlement considered itself to be the superior legislator of the kingdom. Today's lit de justice, as d'Argenson put it, would redress the tilting balance between the monarch and the Parlement, the paramount issue of the day.

The keeper of the seals addressed the issue of remonstrances, to which the annulment decree and the letters patent devoted their first six articles. These articles reaffirmed that fundamental concession of the Declaration of Vincennes by which the Parlement could issue remonstrances before it registered laws, provided that it took no more than one week to do so. But in reaction to recent events, the articles imposed new restrictions upon remonstrances, 
more in the spirit of Colbert and Louis XIV. The decree and letters patent ordered the Parlement never to make remonstrances or representations about, and certainly not to deliberate upon, laws that the king did not send it, a restriction obviously prompted by its claim to jurisdiction over the recoinage edict.

If, in the absence of remonstrances, the Parlement did not register a law within one week of deliberating upon it, then that law would be deemed registered and sent down to subordinate tribunals as though it had been. This provision restated article 5 of title I of the ordinance of 1667 and served notice that, although Louis XIV had never invoked this authority, the regency government might well choose to do so. If the Parlement did not produce its remonstrance on time, then the law in question would, again, be treated as registered. Once the government had answered a remonstrance, the Parlement must register the new law without delay. In addition, the government, not the Parlement, would decide whether a remonstrance would take oral or written form.

These articles permitted the royal administration to set the complete schedule under which remonstrances would be written, delivered, answered and ended. They also enabled ministers to influence the topics of remonstrances, by restricting them to laws sent directly to a tribunal. They permitted the government to choose whether remonstrances would be presented with greater or lesser éclat, orally or in writing. Finally, it seems likely that d'Argenson intended to use these new powers to edit future remonstrances, as he had done with the January remonstrance of the Parlement of Rennes. In sum, d'Argenson revoked the spirit and narrowed the scope of the Declaration of Vincennes, upholding, in his view, the rightful legislative authority of the king.

After dealing with remonstrances, the articles shifted to other issues. Article seven commanded the Parlement never to invite other courts to any association, union, confederation or assembly, without royal permission. Obviously d'Argenson had not forgotten the tribunal's earlier attempt to rally its sister courts against the recoinage edict. The next article renewed a command of Francis I, periodically restated, that the Parlement refrain from deliberating upon any financial issues whatsoever or, indeed, upon any affairs of state. All the tribunal's recent decrees, deliberations, and other acts concerning finances and the state were overturned. The concluding articles vigorously quashed its financial decree of 12 August as inconsistent with royal authority. That decree, together with the equally offensive decree of 20 June and any documents that had contributed to them, were to be ripped from the Parlement's registers and archives and the Regency Council's decree inserted in their place, as a permanent reminder of the king's authority. (This last punishment, however, did not take place.)

After Gilbert read the Council decree and the letters patent, d'Argenson turned to the avocat-général Guillaume de Lamoignon, the brother of the président à mortier, for the recommendations of the gens du roi. Lamoignon, having been warned that the government would seize his property if he did not cooperate, obediently advised the Parlement to register the legislation. First 
President Mesmes, also invited to speak, asked for time in which the Parlement might deliberate upon the new laws, the stalling tactic that the magistrates had selected in their hurried discussions earlier that morning. But d'Argenson paid no attention. He strode purposefully along the benches where sat the peers, dignitaries and magistrates, and pretended to listen to their opinions. Then he approached the king, paused briefly before him, turned and declared, with a whiplash in his voice, 'The king wishes to be obeyed and on the spot'. At this, all the judges, presidents and councillors alike, seemed to collapse into themselves, bowing their heads in despair, Mesmes's chin falling almost to his knees.

Under traditional procedure, the lit de justice would have been at its end, the king having issued his orders and making ready to depart. But in an unprecedented move, d'Argenson registered the new laws on the spot, the royal seals at hand, the burner for sealing wax glowing with flame, and Gilbert standing by with the Parlement's register. Since six legislative acts were involved, it took time to get the job done. The lit de justice, which began at 10 a.m., concluded around 2 p.m. A dejected company of magistrates finally made its way back across the Seine, leaving only the first president behind. After the lit de justice, the duc du Maine summoned Mesmes to his apartment at the Tuileries where, with guards at his doors, he had languished through the entire ceremony. There the duchesse, in a rush of her Condé blood, abused the first president for an hour and finally mounted a stool (since she was small of stature), seized his cravat and slapped him hard. ${ }^{25}$

Only in the days after a lit de justice, no matter how formidable, could a government know for sure if it had succeeded in its effort to intimidate a parlement, as the Introduction to this study has argued. In this case, the apparently vanquished magistrates recovered overnight and, in a plenary session on 27 August, began to plan their comeback. For the next forty-eight hours it appeared that this lit de justice, like so many before 1661, had failed. First President Mesmes, obviously invigorated by his encounter with Maine, led the way, this time unequivocally. As the first president told it, the lit de justice had dealt the Parlement the hardest blow that it had ever suffered in its long history, and it must rise to this unprecedented challenge.

Also stung by the lit de justice, his colleagues rushed to agree, in one angry discourse after another. D'Aligre, a président à mortier, said the only question was whether the Parlement should be rigorous or prudent in its new struggle. For the moment, the magistrates decided, prudently, to compose a full written record of the ceremony, intending to discredit the new legislation by establishing that they had neither deliberated nor been heard on it. Twenty-four deputies, ten from the Grand-Chambre and two each from the seven Enquêtes and Requêtes chambers, were to assemble on Sunday, 28 August, in the Chambre Saint-Louis to draw up the Parlement's account of the lit de justice. The Parlement would meet on Monday, 29 August, to approve the document.

Much more significantly, the tribunal also charged the deputies to consider 
what it could do against the lit de justice and the new laws registered therein. In his opening remarks, the first president had proposed that the magistrates read all the laws in their next session to decide what to do about them. This invited the Parlement to find ways to undermine the legislation, much as it had done after the lit de justice of January 1648. In addition, Mesmes identified d'Argenson as a good subject for a judicial investigation in his own right. Président à mortier Le Peletier proposed that some deputies visit Chancellor d'Aguesseau at Fresnes, his rural home and place of exile, to ask if he had surrendered the seals voluntarily, as d'Argenson's letters of provision alleged. Another magistrate revived the idea of interrogating John Law. In short, the judges who had prudently agreed to document the lit de justice did not intend to stop there. They were prepared to deepen the crisis and to challenge d'Argenson and, by implication, the regent with every political and judicial weapon at their disposal.

On 28 August, the deputies met for almost five hours in the Chambre SaintLouis. Their number included such leading activists as the outspoken président aux enquêtes Frizon de Blamont; Councillor Henri-Charles Feydeau, the son of another fiery Enquêtes president; Armand de Saint-Martin, an Enquêtes councillor known for his combative instincts; and Councillors Pucelle and Ferrand, still smarting from having been booted off the administrative councils of the regency. Mesmes himself was a deputy. By themselves, the deliberations on 27 August and the session of the deputies on 28 August violated d'Argenson's order to the Parlement not to discuss affairs of government. We can only assume that the deputies would have brought strong recommendations to the Parlement on 29 August, a further infraction. Thanks to his informants, d'Argenson must have known for sure. ${ }^{26}$

The keeper of the seals struck first and stopped the Parlement before it could intensify this clash. During the night of 28-29 August, he sent armed musketeers to arrest three of the most prominent Chambre Saint-Louis deputies Frizon, Feydeau and Saint-Martin. Twenty to thirty musketeers arrived between 2 and 3 a.m. to arrest them at their homes. When Saint-Martin's porter refused to open the door, the musketeers hacked through with axes and took the judge into custody anyway. Masters of requests searched the houses for incriminating documents, filling two cartons with suspicious papers belonging to Frizon. Their searches complete, the musketeers bundled the magistrates into two large carriages and drove them to the city of Orléans, en route to farflung prisons on the periphery of France.

When the Parlement assembled early that morning, the magistrates naturally clamoured for the release of their unfortunate colleagues. A deputation of sixty-three judges, almost a third of the full Parlement and drawn from all its chambers and ranks, proceeded to the Tuileries that afternoon to plead their case en masse before the king, the regent and the assembled court. Although the large deputation was meant to impress, an unmoved d'Argenson replied 
coldly that affairs of state, which had caused the arrests, belonged to the king alone and thus fell outside the jurisdiction of the tribunal. What happened to the prisoners, d'Argenson declared, would depend upon the future behaviour of the magistrates as a group. Contemporaries recorded his terse reply as a further humiliation for the deputies who, despite their numbers, came away empty-handed, their plans for further resistance to the lit de justice definitively quashed. ${ }^{27}$ This last episode, no more than an empty gesture intended to preserve appearances, provided the denouement to the long confrontation of 1718 and marked the final defeat of the Parlement, in terms of the regency of Philippe d'Orléans.

For 1718 , the expression lit de justice should be used, in the manner of synecdoche, one part standing for the whole, to designate all the related events that occurred in the four days from 26 to 29 August, before and after the ceremony itself. In this extended sense, we can agree with the gazeteer Buvat that the lit de justice changed everything.

It handed the Parlement a stinging defeat and boosted the political authority of the regent. Because of the lit de justice, the Parlement ceased to resist d'Argenson, Law and the policies of Orléans. The deputies to the Chambre SaintLouis never reported, and the Parlement abandoned any further thought of undermining the laws registered on 26 August. The arrest of the three judges, by no means the only opposition spokesmen, stood as a warning to others. Those magistrates who had been the most vocal throughout the disputes of 1717 and 1718 fell silent; and First President Mesmes fell ill, suffering an apparent stroke.

The influence of the faction of the duc du Maine waned; he and the duchesse withdrew to their property at Sceaux and did not receive visitors. In September, the regent terminated his experiment with administrative councils, with the exception of the Marine Council, and began to govern, like Louis XIV, through ministers and secretaries of state. D'Argenson naturally emerged stronger than ever. 'The Parlement wanted to ruin him', Buvat observed, 'and he ruined the Parlement'. In a way roughly comparable to the initiatives of Chancellor Maupeou in the 1770 s, the lit de justice rearranged political forces to the advantage of the government. ${ }^{28}$

New appointments in the Parlement underlined the point. On 5 December 1718, Germain-Louis Chauvelin, an avocat-général who had supported d'Argenson, rose to the dignity of président à mortier; and Pierre Gilbert de Voisins, who had served with distinction on Noailles's Council of Finances, replaced him as the new avocat-général. The regent thus placed loyal supporters on the gens du roi and among the presidents. In addition, André Potier de Novion, a loyalist président à mortier who out of disgust had scarcely attended Parlement sessions in 1718, resumed his service. ${ }^{29}$ These magistrates formed the nucleus of a new loyalist faction, which would steadily grow.

In a narrow sense, it had all come down to the effective use of force, as the 
diarist Barbier noted, comparing d'Argenson favourably with Mazarin, in another reference to 1648 . The keeper of the seals apparently shared this view. Weeks before the lit de justice, d'Argenson put it bluntly to his son, a junior councillor in the tribunal, "My son, does your Parlement have any troops? We have 150,000 men. That's what this comes down to.' ${ }^{30}$ Intimidation and coercion do not, of course, tell the full story. The regent's opponents in, and outside the Parlement, turned out to lack the daring, skill and strength that he and Saint-Simon imputed to them. The lit de justice surprised the government's opponents and gave it a psychological advantage, while the arrests of their colleagues sapped the courage of the judges. Irresolution and weakness in one's adversaries often lead to a good result.

On the other hand, these adversaries, especially the judges, yielded not only to physical strength but to the vitality of the ideas of absolute government and the legacy of Louis XIV, itself far from moribund. A small but determined circle of the regent's advisers, who still believed in absolute government, fortified the regent's inclination to defend it. Personalities, character and ideas made the difference in 1718, turning back the Parlement's efforts to reassert constitutionalist ideas and to restore them to registration procedure, depriving it even of that 'victory in defeat' with which it emerged from the Fronde. ${ }^{31}$

\section{Notes}

1 Frédéric d'Agay, 'Argenson', in Bluche, Grand Dictionnaire, pp. 102-103; SaintSimon, Mémoires, XXXIII, 34-36; Buvat (?), Gazette de la Régence, pp. 230-232, 236; Dangeau, Journal, XVI, 194 (18 September 1715). For d'Argenson's prior disputes with the Parlement, see El Annabi, Parlement de Paris, pp. 102-103, 282, 341-342. D'Argenson's son René-Louis de Voyer was a young councillor in a chambre des enquêtes of the Parlement. See his celebrated Journal et mémoires du marquis d'Argenson, ed. E.J.B. Rathery (9 vols; Paris, 1859-1867), I, 41.

2 Flammermont, Remontrances, I, 65; AN, U 416: 22 February 1718; Buvat [?], Gazette de la Régence, p. 237; U 416: 31 January 1718 (noting the Parlement's aversion to registering d'Argenson's letters of appointment to be keeper of the seals).

3 AN, U 416 and 420: 4 March 1718. The ambiguous role of Mesmes, the friend of the duc du Maine, is noted in Buvat [?], Gazette de la Régence, p. 233.

4 La Bourdonnaye, président à mortier, Paris, to Parlement of Rennes, 19 February, 14 and 15 March 1718, AD, I-V, IBc 2bis; IBb 330 (Registres secrets): 23 February, ff. 7v-8v; 17 March, ff. 17rv-18r; and 8 April 1718, ff. 25v-28v; IBb 660 (Registres secrets): 28 April 1718 (final report of La Bourdonnaye on the Parlement's deputation to Paris). See also Le Moy, Parlement de Bretagne, pp. 117-121; idem, Remontrances, pp. 6-8.

5 Faure, Banqueroute de Law, pp. 143-145; Frank C. Spooner, The International Economy and Monetary Movements in France, 1493-1725 (Cambridge, Mass., 1972), pp. 249, 290, 329-330; Edmond-Jean-François Barbier, Journal historique et anecdotique du règne de Louis XV (4 vols; Paris, 1847-1856), I, 6.

6 AN, U 416 and 420: sessions of 2, 13, 14 and 15 June 1718; Saint-Simon, 
Mémoires, XXXV, 347-349, contains the accounts in the Parlement's secret register, AN, X1A 8435; Law [?], 'Histoire des finances', 333; Buvat [?], Gazette de la Régence, p. 263. In 1655, the Parlement of Paris also strongly resisted the principle of devaluation and challenged the competence of the Cour over a coinage edict: Hamscher, Parlement of Paris, pp. 91-93. Hardy, Judicial Politics, pp. 102-104, and Shennan, Parlement of Paris, pp. 287-288, failed to note the interaction of the Parlement with the other superior courts of Paris.

7 AN, U 416 and 420: sessions of 17-19 June 1718; Barbier, Journal historique, I, 8; Buvat (?), Gazette de la Régence, p. 263; Flammermont, Remontrances, I, 69-74 (the representations and the regent's rejection of them).

8 AN, U 416 and 420: 20-21 June 1718; Flammermont, Remontrances, I, 74-75; Law (?), 'Histoire des finances', 333; Buvat, Journal, I, 279. Scholars tend to accept Glasson's verdict that on this occasion the Parlement encroached upon royal authority: Glasson, Parlement de Paris, II, 31; Leclercq, Régence, II, 152; Shennan, Parlement of Paris, p. 289; Hardy, Judicial Politics, p. 106.

9 BN, F. 23,673 (Regency Council), f. 89v: 20 June 1718; BN, N.a.f., 9,771, ff. 63r, 138r; AN, U 416 and 420: 21 June 1718; U 416: 24 June 1718; AN, E 1994, f. 79rv (20 June 1718) and f. 82rv (21 June 1718); Buvat [?], Gazette de la Régence, p. 265; Saint-Simon, Mémoires, XXXV, 352-353. Dodun, a président des enquêtes, stayed in the Council of Finances, and Councillor Goislard remained in the Council of the Interior; but they no longer attended sessions in the Parlement.

10 AN, U 416 and 420: 19, 22, 25, and 27 June 1718; AN, X 1B 8899 (Minutes. Conseil): 27 June 1718; Flammermont, Remontrances, I, 77-84; Buvat, Journal, I, 280. The accounts in Hardy, Judicial Politics, p. 108, and Shennan, Parlement of Paris, pp. 288-289, are incomplete.

11 BN, F. 23,673 (Regency Council): sessions of 27 and 30 June 1718, ff. 92rv, 93r; AN, U 416: 1 July 1718; Buvat (?), Gazette de la Régence, p. 269.

12 Flammermont, Remontrances, I, 85-87; BN, Fonds fr., 9771, ff. 102rv-103rv; and AN, U 420. For mid-century issues of representation, see Keith Michael Baker, 'Representation Redefined', in idem, Inventing the French Revolution. Essays on French Political Culture in the Eighteenth Century (Cambridge, 1990), pp. 231, 233. Hardy, Judicial Politics, pp. 111-112, Shennan, Regent, pp. 87-88, and idem, Parlement of Paris, p. 289, do not give d'Argenson's statement the attention it deserves.

13 An unknown witness took notes on d'Argenson's statement and sent a transcript to First President Camus de Pontcarré of the Parlement of Rouen: AD, S-M, $1 B 5446$.

14 AN, U 416 and 420: 4, 8 and 12 July 1718. The quotations are from notes taken on the spot by the greffier Gilbert, in U 420. As a recent retiree, with more than twenty years of service, President Cochet held lettres d'honneur, by which he still attended sessions and enjoyed the right to speak and to vote.

15 AN, U 416: 12, 13, 14, 18, 26 and 27 July 1718; U 420: 14 and 26 July 1718; U 226 (Conseil secret): 14 and 27 July 1718, ff. 427rv-428r, 472v-473r. Most of the présidents à mortier supported the first president's preference for a brief presentation of the remonstrance; but obviously the government had little support among the councillors.

16 Flammermont, Remontrances, I, 88-105; BN, N.a.f., 9,771, f. 136rv ('Projet de Réponse aux Remonstrances'); Dangeau, Journal, XVII, 351 (31 July 1718). Shennan, Regent, pp. 88-89, found the remonstrance 'extreme', as, in effect, did 
Hardy, Judicial Politics, p. 114. The Parlement published its representations and remonstrances in pamphlet form, along with the collateral remonstrances of the other superior courts of Paris, in 'Recueil des Remontrances faites au Roy en M.DCC.XVIII. par ses cours souveraines . . ., AN, U 416, 18 August 1718, and University of Delaware, Special Collections, K.F815/P252re.

17 AN, U 226 (Conseil secret): 1 August, ff. 478r-479rv; 6 August, ff. 493v-494r; 9 August, ff. 507v-508r; 11 August, ff. 508rv-509rv; and 12 August, ff. 513v-515r; U 416: 1, 6, 9, 11-12, 17-20 August; and U 420: 6, 11 and 12 August 1718; Law [?], 'Histoire des finances', 330-336; Faure, Banqueroute de Law, pp. 117-119, 126-128, 132-133, 147-149; Barbier, Journal historique, I, 8; Dangeau, Journal, XVII, 357; Flammermont, Remontrances, I, 106-107; Marion, Histoire financiére, I, 93-95; Lüthy, Banque protestante, I, 304-310.

18 AN, U 226 (Conseil secret): 22 August 1718, f. 560r, and U 416 and 420: 22 August 1718; Saint-Simon, Mémoires, XXXV, 17, and Law [?], 'Histoire des finances', 336, assessed the decree as an assault upon royal sovereignty, a view implicitly adopted by Leclercq, Histoire de la Régence, II, 157-158, and explicitly by Shennan, Parlement of Paris, p. 290.

19 Saint-Simon, Mémoires, XXXV, 30-31; Michel Antoine, Le Gouvernement et l'Administration sous Louis XV. Dictionnaire biographique (Paris, 1978), pp. 99 (Fagon), 138-139 (La Force). Negotiations for the Quadruple Alliance concluded on 2 August; its financial clauses made the regent all the more anxious about the Parlement: Faure, Banqueroute de Law, p. 164.

20 Saint-Simon, Mémoires, XXXV, 26-82; Leclercq, Histoire de la Régence, II, 159-166.

21 BN, Fonds fr., 23,673 (Regency Council): 21 August 1718, ff. 97v-98r; SaintSimon, Mémoires, XXXV, 82; BN, N.a.f., 9,771, ff. 158v-159r, which includes the d'Argenson quotation, is a memorandum upon which he based his report to the Council. Dangeau, Journal, XVII, 361-362 (21 August), shows that some Council members talked about what happened at this session. The Council's annulment decree, backdated to 21 August, is in AN, E 1994, ff. 113rv-121r, and Isambert, Recueil général, XXI, 159-162. D'Argenson did not bring this decree to the Council for approval in its final form until 26 August, the day of the lit de justice. The Parlement did not, therefore, 'ignore' the decree on and after 21 August, despite the assertions in Hardy, Judicial Politics, pp. 120-121, 125.

22 Saint-Simon, Mémoires, XXXIV, 202; XXXV, 103, 137, 140; d'Argenson, Journal et mémoires, I, 39, 41. Orléans's mother was Elisabeth Charlotte, duchesse d'Orléans (1652-1722), known in Germany as Liselotte von der Pfalz and in France as Madame or Madame Palatine. See her letters of 27 and 30 August, and 21 September 1718, in Elisabeth Charlotte Orléans, duchesse d', A Woman's Life in the Court of the Sun King. Letters of Liselotte von der Pfalz, 1652-1722, trans. Elborg Forster (Baltimore, 1984), pp. 216-218.

23 Leclercq, Histoire de la Régence, I, 168-170, drew upon Saint-Simon, Mémoires, XXXV, 142-163. For details, see Barbier, Journal historique, I, 9; Buvat [?], Gazette de la Régence, p. 279. The clerk Delisle, already at work at 6 a.m., wrote 'Jour Remarquable' at the top of the page which began his transcription of the events of 26 August, 1718: U 416.

24 BN, Fonds fr., 23,673 (Regency Council): 26 August 1718, ff. 98v-99rv; SaintSimon, Mémoires, XXXV, 170-210, provides a more complete, if biased, account of 
this Council session. At the request of Saint-Simon, a friend of Toulouse, Orléans restored Toulouse to his princely honours for the duration of his life only, without the capacity to transmit them to heirs.

25 For the lit de justice, see especially AN, U 416: 26 August 1718 (which contains the d'Argenson quotation); a procès-verbal signed by Mesmes and d'Argenson; AN, X 1B, 8900: another procès-verbal; BN, Actes R., F. 21,290 (69), the official version; Flammermont, Remontrances, I, 108-111, offers another official account; SaintSimon, Mémoires, XXXV, 210-235, is the classic eyewitness account, despite its bias; see also Dangeau, Journal, I, 370-372 (26 August 1718); Barbier, Journal historique, I, 9-11; the best secondary treatments are Leclercq, Régence, II, 161-187, and Hardy, Judicial Politics, pp. 125-134. For an analysis of the documents which provide accounts of this lit de justice, see Boislisle's note in Saint-Simon, Mémoires, XXXV, 224-225, n. 1, and Hardy, Judicial Politics, p. 130, n. 1. The lit de justice legislation consisted of the original letters of provision for d'Argenson's office of keeper of the seals, the council decree and the letters patent for the Parlement of Paris, and three edicts concerning Maine, Toulouse and Bourbon. The minutes of the Parlement's decrees of 20 June and 12 August 1718 were not, after all, ripped from its registers, as seen in AN, X 1B 8899-8900. Mesmes's encounter with the duchesse du Maine is described in Saint-Simon, Mémoires, XXXV, 266-267, and in BN, Dossiers bleus, 445 ('De Mesmes'), f. 5r.

26 AN, U 226 (Conseil Secret), f. 575v (27 August 1718); AN, U 416 (for the charge to the Chambre Saint-Louis deputies and the names of the deputies) and U 420: 27 August 1718.

27 AN, U 416: 29 August and 14 November 1718; Saint-Simon, Mémoires, XXXV, 365-372, reproduces the Parlement's secret register entries for its sessions of 29-31 August and 3, 5 and 7 September 1718; Flammermont, Remontrances, I, 116-118 (Parlement's entreaty of 29 August); Barbier, Journal historique, I, 13-16; Dangeau, Journal, XVII, 373-375; and Saint-Simon, Mémoires, XXXV 290-291. The authorities took Feydeau to the Ile d'Oléron and Saint-Martin to the Ile de Ré, both off the coast of La Rochelle, while Frizon was relegated to the SainteMarguerite island fortress on the Mediterranean.

28 Buvat [?], Gazette de la Régence, pp. 275, 286; Saint-Simon, Mémoires, XXXV, 271 (a good analysis of the Parlement's defeat); Leclercq, Régence, II, 189, endorsing SaintSimon's view. Hardy quixotically minimized the importance of the lit de justice, in Judicial Politics, p. 137, and Shennan gave it scant attention in Parlement of Paris, p. 291, and Regent, p. 90 (mistakenly locating it in the Louvre).

29 AN, U 416: 5 December 1718. Chauvelin became keeper of the seals in 1727, Gilbert rose to high rank in the councils of the king, and Potier became first president of the Parlement in 1723.

30 Barbier, Journal historique, I, 14-15; d'Argenson, Journal et Mémoires, I, 23.

31 Moote, Revolt of the Judges, p. 375 ('victory in defeat'). Louis XVI found no comparable ideological stalwarts upon whom he could rely; see Munro Price, Preserving the Monarchy. The comte de Vergennes, 1774-1787 (Cambridge, 1995). 